\title{
PENGOLAHAN LIMBAH CAIR KELAPA SAWIT MENGGUNAKAN MEMBRAN BERBASIS KITOSAN, PVA DAN SILIKA
}

\author{
PROCESSING OF PALM OIL LIQUID WASTE USING CHITOSAN BASED \\ MEMBRANE WITH ADDITION OF PVA AND SILICATE
}

\author{
Ida Febriana ${ }^{1, *}$, Siti Chodijah $^{2}$, Husaini ${ }^{3}$, Liza Novriani ${ }^{4}$ \\ 1, 2, 3,4 Politeknik Negeri Sriwijaya, Jl. Srijaya Negara Bukit Besar Palembang. 30139 \\ ${ }^{2}$ Instansi B, alamat lengkap dan kode pos \\ *Ida Febriana. 082186505286 \\ e-mail: i.febriana@yahoo.com
}

\begin{abstract}
ABSTRAK
Perkembangan teknologi membran sebagai unit pengolah limbah saat ini sangat pesat dan banyak digunakan dalam proses pemisahan, seperti limbah cair kelapa sawit. Tujuan dari penelitian ini membuat membran berbasis kitosan, PVA dan silika dengan variasi komposisi dan tekanan sehingga dapat diketahui kondisi optimum aplikasinya dalam proses pemisahan limbah cair kelapa sawit. Metode pembuatan membran ini adalah inversi fasa, yaitu proses sebuah polimer diubah secara terkendali dari fasa cair ke fasa padat. Penelitian ini diawali dengan tahap pembuatan membran kitosan, PVA, dan silika untuk kemudian dilakukan proses pemisahan limbah cair kelapa sawit yang sebelumnya sudah dilakukan pengolahan awal, kemudian dilanjutkan dengan aplikasi pada alat "dead-end". Karakterisasi membran berbasis kitosan, PVA, dan silika telah dilakukan dengan penentuan fluks, koefisien rejeksi, serta morfologi dan ukuran pori membran menggunakan SEM. Dari hasil penelitian didapatkan kondisi optimum penurunan parameter pada komposisi bahan membran 70\%:25\%:5\% dengan tekanan 1 bar. Kata Kunci : Membran Kitosan, PVA, dan Silika, Limbah Cair Kelapa Sawit, Fluks, Rejeksi.
\end{abstract}

\begin{abstract}
The development of membrane technology as a waste treatment unit is currently very rapidly and widely used in the separation process, such in palm oil liquid waste. The purposes of this research were to develop membranes based on chitosan, PVA and silica with variation in composition and pressure; to evaluate the optimum condition of their application in separation process of oil palm liquid waste.. The membranes were developed using phase inversion method, i.e. the process of controlled polymer modification in order to change from liquid to solid phase. The preprocessed oil palm liquid waste was then fed into dead-end membrane apparatus for separation. Characterization of membrane based on chitosan, $P V A$, and silica has been done by determination of flux, rejection coefficient, and morphology and pore size of membrane using SEM. The optimum condition of parameter degradation on the composition of membrane material was $70 \%: 25 \%: 5 \%$ with pressure of 1 bar.

Keywords: Chitosan, PVA, and Silica membrane, Palm oil liquid waste, Flux, Rejection
\end{abstract}

\section{PENDAHULUAN}

Kelapa sawit merupakan salah satu komoditas pertanian utama Indonesia yang telah berkembang dari 300.000 hektar perkebunan yang menghasilkan 720.000 ton kelapa sawit mentah di tahun 1980, menjadi 8,9 juta hektar yang mengahasilkan 23 juta ton CPO di tahun 2011. Indonesia saat ini merupakan produsen minyak kelapa sawit terbesar di dunia, tercatat sekitar 608 pabrik pengolahan kelapa sawit [1].

Proses pengolahan kelapa sawit menjadi minyak sawit mentah atau Crude Palm Oil (CPO) menghasilkan limbah cair sawit sebanyak 2500 l/ton CPO. Limbah cair kelapa sawit ini mengandung Chemical Oxygen Demand (COD) rata-rata sebesar 21.280 mg/l, Biochemical Oxygen Demand (BOD) rata-rata sebesar $34.720 \mathrm{mg} / \mathrm{l}$, minyak lemak rata-rata sebesar 3.075 mg/l dan $\mathrm{pH}$ rata-rata sebesar 4 [2]. Sistem 
pengolahan limbah cair kelapa sawit di industri adalah dengan kombinasi proses fisik seperti sedimentasi dan proses biologi, baik secara anaerob atau aerob. Kelemahan dari sistem pengolahan konvensional adalah waktu pengolahan yang lama (10-90 hari) dan membutuhkan lahan yang sangat luas $( \pm 6$ kali dari luas areal pabrik).

Berdasarkan penelitian [3] membran kitosan-PVA dengan komposisi kitosanPVA 75\%:25\% dan 80\%:20\%. Membran ini diaplikasikan pada limbah kain jumputan. Berdasarkan hasil analisa pori menggunakan metode SEM membran dengan perbandingan 75\%:25\% memiliki pori yang lebih kecil daripada membran dengan komposisi 80\%:20\% yaitu berkisar 366nm-987nm.

Penelitian sebelumnya tahun 2012, telah dibuat membran kitosan-PVA dengan perbandingan 100\%:0\%, 75\%:25\%, 50\%:50\%, 25\%:75\%, 0\%:100\% (v/v). Pada pembuatan membran kitosan-PVA juga dilakukan penambahan Poli Etilen Glikol (PEG-6000) dengan konsentrasi 2,5\% b/v sebagai porogen. Membran dengan perbandingan 75\%:25\% memiliki kekuatan mekanik terbaik yaitu sebesar 36,926 kgf. Selain itu membran dengan perbandingan tersebut memiliki ukuran pori yang lebih rapat yaitu berkisar 0,01-0,15 $\mu \mathrm{m}$ [4].

Penambahan silika pada larutan kitosan membuat membran menjadi porogen sehingga fluks permeat dan permeabilitas air menjadi tinggi. Permeabilitas membran secara keseluruhan dipengaruhi bagaimana poripori membran tersusun [5]. Menurut penelitian sebelumnya juga [6] tentang

penggunaan membran kitosan-PVA untuk penurunan COD dan BOD limbah cair kelapa sawit, konsentrasi kitosan dan kecepatan pengadukan memberikan pengaruh terhadap kinerja membran komposit kitosan-PVA dalam aplikasi filtrasi POME. Nilai fluks terbesar didapatkan pada membran dengan konsentrasi kitosan 70\% dan kecepatan pengadukan 100 rpm.

Dari beberapa penelitian sebelumnya komposisi terbaik kitosan ialah berada pada rentang 70\%-75\%. Sementara untuk meningkatkan porogen dapat digunakan Silika dan juga PEG. Untuk itu pada penelitian ini, peneliti menggabungkan campuran bahan Kitosan, PVA, Silika dan juga $P E G$ sehingga nantinya bisa didapatkan membran dengan pori yang lebih kecil, sehingga akan lebih optimal untuk menahan padatan yang terlarut dalam limbah. Membran ini diaplikasikan pada limbah cair kelapa sawit mengingat Indonesia merupakan negara produsen kelapa sawit terbesar di dunia dengan pabrik mencapai 608 buah pabrik. Penelitian ini juga dilakukan untuk mempelajari pengaruh rasio komposisi bahan membran terhadap kinerja membran dalam aplikasi filtrasi pada POME untuk penurunan COD, BOD, dan TDS. Hasil penelitian diharapkan dapat menjadi alternatif metode pengolahan limbah POME dalam penurunan COD, BOD, dan TDS sehingga dapat membantu mengatasi masalah pencemaran lingkungan.

\section{BAHAN DAN METODE}

\section{Bahan Penelitian}


Bahan yang digunakan dalam penelitian ini yaitu limbah cair kelapa sawit, serbuk kitosan, polivinil alcohol, poli etilen glikol (PEG), silica, asam asetat, $\mathrm{NaOH}$, tawas $\left(\mathrm{Al}_{2} \mathrm{SO}_{4}\right)$, dan air aquadest

\section{Peralatan Penelitian}

Alat yang digunakan dalam penelitian ini adalah sebagai berikut erlenmeyer, gelas kimia, magnetic stirrer, motor pengaduk, $\mathrm{pH}$ meter, neraca analitik, turbiditi meter, kaca arloji, spatula, pipet tetes, pipet ukur, bola karet, peralatan filtrasi, plat kaca datar, selotif sel, hot plate, water batch, corong gelas, thermometer, dan oven.

\section{Metode Penelitian}

Perlakuan Awal

Untuk memperoleh limbah cair kelapa sawit yang memenuhi standar sesuai peraturan Gubernur Sumatera Selatan No.8 tahun 2012 dibutuhkan beberapa tahapan mulai dari pengambilan sampel limbah cair kelapa sawit hingga diproses atau difilter menggunakan membran. Sebelum dilakukan proses filtrasi menggunakan membran, limbah cair kelapa sawit ditambahkan dengan koagulan yang berkonsentrasi 1000 ppm, 2000 ppm, dan 3000 ppm. Variasi konsentrasi koagulan ini dilakukan untuk mengetahui berapa konsentrasi optimum pada limbah cair kelapa sawit ini yang nantinya akan dijadikan variabel tetap untuk proses selanjutnya. Dari pengujian beberapa parameter seperti TDS,COD, dan pH dapat dianalisa bahwa kondisi optimum dari penambahan koagulan ini yaitu pada konsentrasi 3000 ppm. Parameter seperti TDS dan COD cenderung mengalami penurunan karena semakin besarnya konsentrasi koagulan semakin banyak pula partikel-partikel yang terendapkan. Sementara nilai $\mathrm{pH}$ menjadi sedikit meningkat seiring dengan penambahan koagulan. Namun $\mathrm{pH}$ yang diperoleh masih memenuhi standar baku mutu air limbah. Peningkatan $\mathrm{pH}$ ini berkaitan dengan penambahan konsentrasi koagulan. Konsentrasi koagulan yang semakin tinggi menyebabkan $\mathrm{pH}$ akan semakin naik karena adanya reaksi antara koagulan $\left(\left(\mathrm{Al}_{2} \mathrm{SO}_{4}\right)_{3}\right)$ dengan $\mathrm{H}_{2} \mathrm{O}$ yang mengakibatkan pembebasan ion $\mathrm{H}^{+}$ sehingga $\mathrm{pH}$ larutan akan bertambah. Jadi berdasarkan penelitian ini konsentrasi koagulan yang optimum yaitu dengan konsentrasi 3000 ppm. Kemudian untuk pengujian selanjutnya digunakan konsentrasi koagulan 3000 ppm. Secara umum proses pengolahan awal dengan penambahan koagulan ini bertujuan untuk membantu proses pengendapan partikelpartikel yang terdapat dalam limbah cair kelapa sawit. Proses ini berdasarkan prinsip koagulasi, flokulasi dan sedimentasi. Pada proses koagulasi terjadi destabilisasi koloid dan partikel dalam air sebagai akibat dari pengadukan cepat dan pembubuhan bahan kimia/koagulan. Akibat pengadukan cepat, koloid dan partikel yang stabil berubah menjadi tidak stabil karena terurai menjadi partikel yang bermuatan positif dan negatif. Pembentukan ion positif dan negatif juga dihasilkan dari proses penguraian koagulan. Proses ini berlanjut dengan pembentukan ikatan antara ion positif dari koagulan (misal $\mathrm{Al}^{3+}$ ) dengan ion negatif dari partikel (misal $\mathrm{OH}^{-}$) dan antara ion positif dari partikel dengan ion negatif dari koagulan (misal SO $4^{2-}$ ) yang menyebabkan 
pembentukan inti flok (presipitat).Segera setelah terbentuk inti flok, diikuti oleh proses flokulasi, yaitu penggabungan inti flok menjadi flok berukuran lebih besar yang memungkinkan partikel mengendap. Penggabungan flok kecil menjadi flok besar terjadi karena adanya tumbukan antar flok. Tumbukan ini terjadi akibat adanya pengadukan lambat. Selanjutnya limbah yang telah dipretreatment dialirkan ke modul membran. Dari proses ini diharapkan setelah melewati membran permeat yang dihasilkan dapat memenuhi standar baku limbah cair kelapa sawit.

\section{Anallisa Awal}

Analisa awal terhadap sampel air limbah kelapa sawit yaitu meliputi analisa pH, TDS, BOD dan COD sebelum air diproses menggunakan membran.

\section{Sintetis Membran}

Membran yang dipakai disintesis menggunakan metode inversi fasa yaitu dengan penguapan pelarut pada suhu pengeringan $80^{\circ} \mathrm{C}$ [7]. Membran dibuat dengan variasi perbandingan Kitosan-PVASilika. Larutan kitosan ditambahkan silika dan diaduk hingga homogen. Setelah homogen larutan tersebut ditambahkan dengan PVA dan 0,25 gr PEG kemudian diaduk kembali hingga homogen. Larutan kemudian dicetak dan dikeringkan selama 24 jam. Film yang terbentuk direndam dalam larutan $\mathrm{NaOH} 1 \%$ untuk melepaskan film dari cetakan. Film membran dicuci menggunakan aquades terlebih dahulu sebelum digunakan.

Variasi komposisi sebagai berikut :

Kitosan: 70\% 70\% 70\% 70\% 70\%

PVA $\quad: 29 \% \quad 28 \% \quad 27 \% \quad 26 \% \quad 25 \%$

Silika : $1 \% \quad 2 \% \quad 3 \% \quad 4 \% \quad 5 \%$

\section{Karakteristik Membran}

Karakterisasi membran bertujuan untuk menentukan uji kelayakan membran sebelum digunakan. Karakterisasi membran ini meliputi:

1. Menetukan Diameter Membran

Membran yang akan digunakan disesuaikan terlebih dahulu dengan diameter alat yang akan digunakan, dengan cara manual menggunakan mistar.

2. Pengukuran Ketebalan Membran

Pengukuran ketebalan membrane dapat dilakukan dengan menggunakan alat SEM, dimana pengukuran dilakukan di lima titik yang berbeda dan ketebalan membrane merupakan rata-rata dari hasil pengukuran.

3. Penentuan Ukuran Pori Membran

Membran yang dihasilkan ditentukan ukuran pori menggunakan alat Scanning Electron Microscopy (SEM). Pemotretan dilakukan pada permukaan dan penampang lintang membran. Ukuran pori membran akan terbaca melalui layar monitor komputer.

4. Penentuan Kandungan Air Membran Membran komposit dalam keadaan basah diletakkan pada alumunium foil yang telah diketahui beratnya (Wb) lalu ditimbang, setelah itu dimasukkan kedalam oven dan dipanaskan pada temperatur $60^{\circ} \mathrm{C}$ selama 6 jam. Setelah itu membran dan alumunium foil ditimbang sampai diperoleh berat yang konstan (Wmk). Kandungan air dapat ditentukan dari perbandingan (Wmb-Wmk) dengan (Wmk-Wmb) dikalikan 100. 


$$
H=\frac{W m b-W m k}{W m b-W b} \times 100 \%
$$

Dimana :

$\mathrm{Wmb}=$ berat membran basah $(\mathrm{gram})$

Wmk $=$ berat membran kering (gram)

$\mathrm{Wb}=$ berat alumunium foil (gram)

$\mathrm{H} \quad=$ kandungan air $(\%)$

\section{Uji Kelayakan Membran}

Prosedur kerja untuk uji kelayakan membran (penentuan fluks) adalah sebagai berikut :

1. Memasang membran pada alat yang akan digunakan

2. Memasukkan umpan yang berupa air aquades kedalam alat

3. Menghubungkan selang ke udara ke alat yang digunakan

4. Mengatur tekanan masuk sebesar 1 bar

5. Menampung permeat dengan menggunakan gelas ukur dan mencatat waktu yang dibutuhkan untuk menghasilkan permeat setiap 10 $\mathrm{ml}$

6. Mengulangi langkah 4-5 dengan mengganti tekanan menjadi 1 bar, 1.5 bar dan 2 bar.

\section{Penentuan Rejeksi pada Limbah Cair \\ Kelapa Sawit}

Membran yang sudah dibuat dan akan diuji, dipotong membentuk lingkaran dengan diameter $\pm 10 \mathrm{~cm}$. kemudian membran diletakkan di bagian alat penguji. Kemudian air limbah dimasukkan kedalam alat dan ditutup dengan rapat. Setelah dialirkan tekanan 1 bar, 1.5 bar, dan 2 bar. Kemudian menampung hasil yang didapatkan untuk dianalisa.

\section{Analisa Akhir}

Permeat yang dihasilkan dari proses penyaringan menggunakan membrane komposit berbasis Kitosan-PVA-Silika di analisa dengan parameter analisa meliputi $\mathrm{pH}$, TDS, COD dan BOD.

\section{Prosedur Analisa}

\section{Penentuan Nilai pH}

Penentuan nilai $\mathrm{pH}$ dilakukan dengan metode pemeriksaan SNI 06-6989.11-2004 yaitu:

1. Elektroda dibilas dengan larutan penyangga $\mathrm{pH} 7$ sebanyak 3 kali, kemudian dikeringkan menggunakan tisu.

2. $\mathrm{pH}$ larutan buffer diukur dan alat diatur sehingga pH menunjukkan angka 7.

3. Elektroda dibilas kembali dengan larutan penyangga $\mathrm{pH}$ sebanyak $3 \mathrm{kali}$, lalu dikeringkan dengan tisu.

4. $\mathrm{pH}$ larutan diukur kembali dan alat diatur hingga skala $\mathrm{pH}$ menunjukkan angka 4. Langkah yang sama dilakukan untuk $\mathrm{pH} 9$.

5. Elektroda dibilas dengan aquadest sebanyak 3 kali dan dikeringkan dengan tisu.

6. Elektroda dimasukkan kedalam sampel yang akan diperiksa pH-nya. $\mathrm{pH}$ meter dibiarkan sampai menunjukkan pembacaan yang tetap.

\section{Analisis COD}

Penentuan COD dilakukan dengan metode pemeriksaan SNI 6989.2-2009 yaitu:

- Standardisasi larutan FAS

$$
\left(\left(\mathrm{NH}_{4}\right)_{2} \mathrm{SO}_{4} \cdot \mathrm{FeSO}_{4} \cdot 6 \mathrm{H}_{2} \mathrm{O}\right) \text { 0,0392 N }
$$

1. Memipet $25 \mathrm{ml}$ larutan sampel kedalam tabung refluks menambahkan $1,5 \mathrm{ml}$ kalium dikromat dan $3,5 \mathrm{ml}$ $\mathrm{H}_{2} \mathrm{SO}_{4}$ 
2. Merefluks larutan sampel tersebut dengan suhu $150{ }^{\circ} \mathrm{C}$ selama 2 jam lalu didinginkan.

3. Memasukkan hasil yang sudah didinginkan dari tabung refluks ke dalam Erlenmeyer

4. Menambahkan 2-3 tetes indicator feroin sampai warna hijau kebiruan

5. Menitrasi dengan larutan 0,0392 N sampai warna berubah menjadi coklat kemerahan (merah bata), mencatat volume titran.

6. Melakukan titrasi blanko.

\section{Perhitungan COD}

\section{Standardisasi FAS}

$$
\mathrm{NFAS}=\frac{\mathrm{ml} \mathrm{K}_{2} \mathrm{Cr}_{2} \mathrm{O}_{7} \times \mathrm{NK}_{2} \mathrm{Cr}_{2} \mathrm{O}_{7}}{\mathrm{ml} \mathrm{FAS}(\text { volume titran })}
$$

\section{Penetapan COD}

$$
\operatorname{COD}\left(\frac{m g O_{2}}{L}\right)=\frac{(a-b) \times N F A S \times 8000}{v}
$$

Dimana:

a adalah volume titran blanko $(\mathrm{ml})$

$\mathrm{b}$ adalah volume titran sampel $(\mathrm{ml})$

$v$ adalah volume sampel (ml)

\section{Analisa TDS}

1. Mempersiapkan sampel

2. Membilas elektroda dengan aquades

3. Meletakkan sampel dalam gelas kimia $250 \mathrm{ml}$

4. Meletakkan elektroda kedalam gelas kimia yang telah diisi sampel

5. Menekan tombol ON

6. Membaca angka pada display sampai menunjukkan pembacaan yang tetap

7. Mencatat data yang diperoleh

\section{HASIL DAN PEMBAHASAN}

\section{Penentuan Fluks Air Murni}

Nilai fluks dan rejeksi merupakan parameter utama dalam menilai kinerja membran [8 ]dan [9]. Penurunan fluks terjadi karena adanya fouling pada membran tetapi adanya fouling dapat meningkatkan rejeksi, untuk mencegah adanya fouling maka membran harus selalu dibersihkan. Faktor yang mempengaruhi nilai fluks antara lain tekanan transmembran, kecepatan cross-flow dan konsentrasi larutan. Permeabilitas merupakan kecepatan permeasi, yang diartikan sebagai volume yang melewati membran persatuan luas dalam satuan waktu tertentu dengan gaya penggerak berupa tekanan. Nilai koefisien permeabilitas air murni menunjukkan kemudahan molekul air untuk melewati membran. Semakin tinggi nilai koefisien permeabilitas, menunjukkan semakin mudah air untuk melewati membran. Permeabilitas membran dilihat dari nilai fluks. Nilai fluks dari suatu membran merupakan laju alir volumetrik suatu larutan melalui membran per satuan luas permukaan membran per satuan waktu. Nilai fluks membran dihitung berdasarkan data volume air yang mengalir melalui luas permukaan membran selama satu jam. Semakin tebal menyebabkan air semakin sulit untuk melewati membran sehingga nilai fluks semakin kecil.

Suatu fenomena umum yang sering ditemukan dalam suatu proses pemisahan dengan membran, yaitu apabila fluks membran besar maka rejeksi juga akan rendah, demikian pula sebaliknya jika rejeksi tinggi maka fluks juga akan rendah biasanya membran yang baik memiliki porositas permukaan yang tinggi (fraksi pori/luas permukaan) dan distribusi ukuran pori yang sesempit mungkin sehingga perlu 
dilakukan suatu optimasi terhadap perlakuan membran untuk mendapatkan fluks dan rejeksi yang tinggi [10]. Permeabilitas membran dapat diketahui dari penentuan fluks air murni dengan volume tertentu persatuan waktu dan luas membran. Penentuan fluks air murni saat uji kelayakan membran dilakukan pada tekanan 1 bar, 1,5 bar, dan 2 bar.

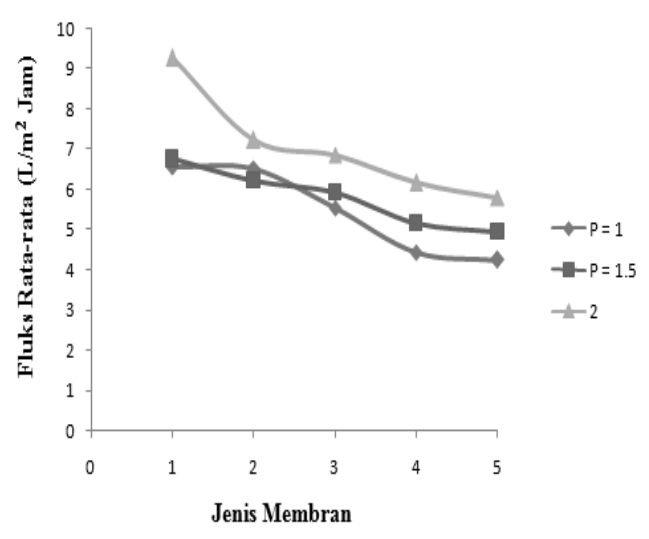

Gambar 1. Grafik hubungan antara membran dan fluks rata-rata air murni masing-masing tekanan

Dari gambar 1. diatas dapat dilihat hubungan antara masing-masing membran dan fluks rata-rata pada tiap-tiap tekanan. Dimana pada grafik ini terlihat masingmasing tekanan mengalami kecenderungan peningkatan fluks, meskipun pada membran 2 saat tekanan 1,5 bar mengalami penurunan fluks. Rata-rata fluks air murni terendah yaitu pada membran 5 saat tekanan 1 bar yaitu 4,24991 l/m2 jam. Semakin besar tekanan maka waktu tempuhnya semakin lama. Hal ini dikarenakan setiap tekanan dinaikkan maka waktu tempuhan yang diperlukan oleh air untuk menembus pori-pori membran akan semakin cepat karena tekanan tersebut akan memperluas pori-pori membran tersebut. Sementara penurunan fluks yang terjadi pada membran 2 saat tekanan 1,5 bar terjadi karena adanya fouling pada membran tetapi adanya fouling dapat meningkatkan rejeksi.

\subsubsection{Penentuan Fluks Limbah Cair Kelapa Sawit}

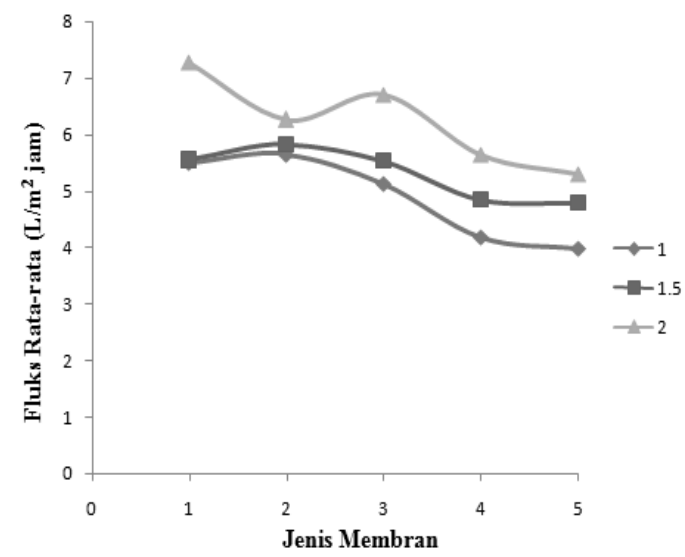

Gambar 2. Grafik hubungan antara membran dan fluks rata-rata limbah cair kelapa sawit masing-masing tekanan

Setelah pengujian fluks air murni, limbah cair yang sudah diberikan perlakuan awal dialirkan pada modul membran. Sehingga pada masing-masing membran dari pengujian ini dapat diketahui pula nilai fluks limbah cair kelapa sawitnya. Secara grafik hubungan antara membran dan fluks rata-rata limbah cair kelapa sawit dapat dilihat pada Gambar 2 diatas. Hasil fluks limbah cair kelapa sawit yang diperoleh tidak jauh berbeda dengan hasil fluks air murni yaitu jika dilhat dari grafik semakin dinaikkan tekanan maka fluks juga akan semakin meningkat. Dari data fluks ratarata membran (dalam hal ini diambil data membran 5) tiap tekanan dari 1-2 bar untuk fluks air murni yaitu 4,24991 I/m2 Jam, $4.940653 \mathrm{l} / \mathrm{m} 2$ Jam dan $5.799334 \mathrm{I} / \mathrm{m} 2$ Jam. Sementara pada fluks rata-rata limbah cair kelapa sawit diperoleh data yang lebih 
rendah dibandingkan dengan fluks air murni yaitu $3.987719 \mathrm{l} / \mathrm{m} 2$ Jam, $4.779631 \mathrm{l} / \mathrm{m} 2$ Jam, dan 5.298953 l/m2 Jam. Hal ini dikarenakan pada limbah cair kelapa sawit terdapat banyaknya padatan suspensi sehingga mengakibatkan pori-pori tersumbat dan menyebabkan waktu tempuhan juga semakin lama yang tentunya fluks yang dihasilkan lebih kecil dibandingkan fluks air murni.

Dari data pengamatan, fluks terendah diperoleh pada membran 5, sementara tertinggi pada membran 1. Penyebabnya ketika komposisi silika dinaikkan maka akan menyebabkan kompaksi. Ketika kompaksi terjadi struktur membran menjadi lebih kompak dan pori-pori membran merapat sehingga menghasilkan penurunan nilai fluks membran begitu pula sebaliknya. Penurunan nilai fluks limbah cair kelapa sawit ini dibandingkan dengan fluks air murni dikarenakan terjadinya fouling (penyumbatan) pada membran yang disebabkan oleh adsorpsi polutan limbah ke dalam membran, sehingga partikel-partikel terakumulasi dan membentuk suatu lapisan pada permukaan dan pori dalam membran yang akan menyebabkan menurunnya fluks membran [11]. Dari gambar 1 dan 2 diatas dapat diketahui bahwa pengaruh penambahan silika pada setiap membran akan menyebabkan kecenderungan penurunan nilai fluks, karena semakin bertambahnya komponen campuran pada membran, maka membran yang dihasilkan juga akan semakin padat.

\section{Analisis Parameter pada Limbah Cair Kelapa Sawit}

Pada penelitian ini masing-masing membran diujikan dengan variasi tekanan dari 1 bar, 1,5 bar dan 2 bar untuk mengetahui tekanan optimal membran serta komposisi optimal pada pengolahan limbah cair kelapa sawit. Berdasarkan data yang diperoleh maka dapat dibuat grafik hubungan antara tekanan dan kandungan COD dan TDS.

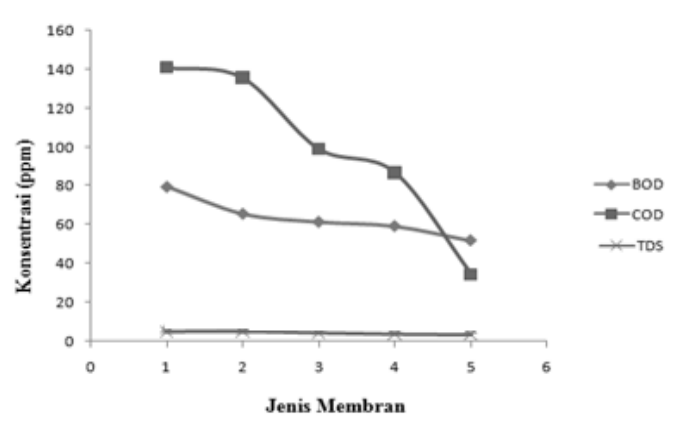

Keterangan: data pengujian pada tekanan 1 bar.
Gambar 3. Grafik hubungan antara konsentrasi dengan komposisi masing-masing membran

Berdasarkan Gambar diatas dapat dilihat bahwa pada saat komposisi silika dinaikkan maka kandungan COD dan TDS akan mengalami penurunan. Semakin banyak komposisi silika maka makin banyak padatan yang tertahan pada membran, karena silika ini dapat membuat pori-pori membran sehingga padatan pada limbah cair kelapa sawit akan semakin sulit menembus pori membran. Kemudian kandungan COD juga mengalami penurunan karena terjadinya fouling membran oleh masuknya polutan limbah ke dalam membran. Partikel-partikel yang terjebak dalam permukaan dan pori-pori membran memperkecil ukuran pori membran. Pori-pori membran yang semakin kecil menyebabkan peningkatan selektivitas membran sehingga bahan 
organik lebih sukar untuk lolos dari pori membran. Sementara untuk hasil COD, dan TDS hasil yang diperoleh juga telah memenuhi persyaratan baku mutu air limbah. Hasil untuk nilai COD yaitu diperoleh dengan kisaran 34,8 ppm hingga 140,85 ppm. Dari data hasil uji parameter didapat kondisi optimum penurunan kandungan COD dan TDS yaitu pada membran 5 dengan tekanan 1 bar.

\section{Koefisien Penolakan (Rejeksi) Limbah} Cair Kelapa Sawit

Koefisien penolakan rejeksi ditentukan sebagai fraksi konsentrasi zat terlarut yang tidak menembus membran berdasarkan beberapa parameter yang dilakukan pada tiap-tiap tekanan operasi dan komposisi bahan membran.

\section{Koefisien Penolakan (Rejeksi) COD pada Limbah Cair Kelapa Sawit}

Pada penelitian, tekanan operasi yang digunakan yaitu 1 bar, 1,5 bar dan 2 bar. Dari gambar 4 dapat diketahui kofisien penolakan (rejeksi COD pada limbah cair kelapa sawit, yang dapat dibuat grafik hubungan membran terhadap koefisien penolakan (Rejeksi) COD pada limbah cair kelapa sawit, yang bisa dilihat pada gambar di bawah ini:

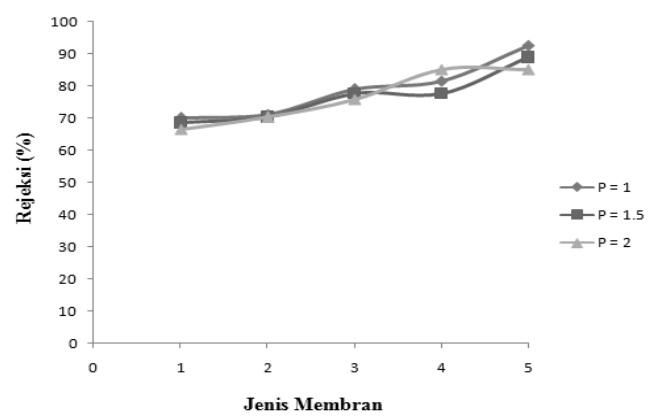

Gambar 4. Grafik hubungan antara jenis membran dengan \% rejeksi cod masing-masing tekanan
Pada Gambar 4. grafik hubungan antara membran dan rejeksi COD pada limbah cair kelapa sawit dapat diketahui bahwa tekanan berbanding terbalik dengan variasi komposisi membran pada rejeksi COD, semakin besar tekanan maka nilai rejeksi cenderung mengalami penurunan dan sebaliknya, semakin besar variasi komposisi membran maka nilai rejeksi COD juga akan meningkat. Penurunan tingkat rejeksi COD disebabkan oleh berkurangnya selektivitas membran yang akan diakibatkan terlalu besarnya tekanan sehingga membuat membran bersifat elastis dari sifat ini akan ada interaksi (gaya tarik menarik) solute yang memiliki ion positif dan negatif, berdasarkan penelitian [4] semakin besarnya muatan ion positif dan negatif maka semakin sulit pula muatan tersebut dapat bersifat jenuh sehingga akan mudah untuk mengikat lagi. Akibatnya terjadi penumpukan partikelpartikel yang tertahan pada pori membran dan zat organik yang harusnya tertahan dapat lolos melewati membran. Sementara peningkatan rejeksi COD saat variasi komposisi membran ditingkatkan adalah karena struktur dari membran semakin rapat akibat kandungan silika yang semakin banyak sehingga fouling yang terjadi juga semakin banyak. Apabila rejeksi COD yang dihasilkan menurun, hal ini menunjukkan bahwa kandungan kontaminannya berkurang seperti zat-zat organic dan sebagainya, mengingat salah satu penyebab tingginya nilai COD disebabkan oleh adanya zat-zat organik dan sebagainya. Dari kelima variasi komposisi membran yang dibuat rejeksi optimum 
terjadi pada membran ke 5 pada tekanan 1,5 bar dan 2 bar.

\section{Koefisien Penolakan (Rejeksi) pH pada} Limbah Cair Kelapa Sawit

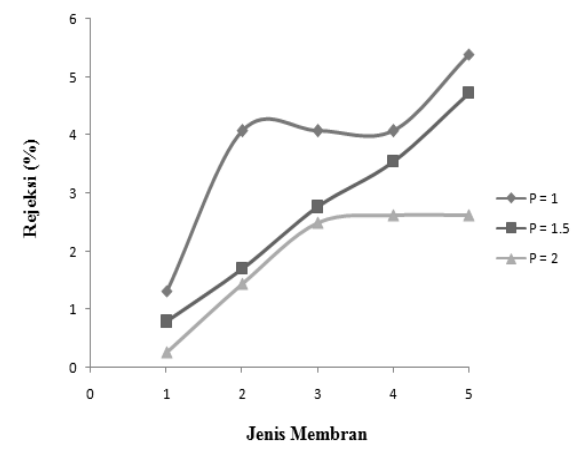

Gambar 5. Grafik hubungan antara jenis membran dengan \% rejeksi ph masing-masing tekanan

$\mathrm{pH}$ adalah gambaran tingkat keasaman suatu bahan. $\mathrm{pH}$ antara lain disebabkan adanya asam-asam organic dari limbah yang memang mengandung asam organic. $\mathrm{pH}$ yang makin menurun artinya makin asam. Dari grafik \% rejeksi yang makin besar artinya pHnya semakin turun. Hal ini dikarenakan bahwa semakin banyak penambahan konsentrasi silika maka nilai $\mathrm{pH}$ akan semakin menurun hal ini disebabkan karena saat konsentrasi silika ditingkatkan sisa kandungan kimia dari koagulan maupun dari sampel awal limbah cair kelapa sawit yang sudah dilewatkan membran banyak tertahan. Jadi semakin tinggi kandungan silika semakin rendah pula nilai $\mathrm{pH}$ nya.

\section{Koefisien Penolakan (Rejeksi) TDS pada Limbah Cair Kelapa Sawit}

Pada gambar 6 dibawah ini terlihat bahwa grafik hubungan antara membran dan rejeksi TDS pada limbah cair kelapa sawit dari tekanan 1 bar hingga 2 bar dengan variasi komposisi membran 1-5 mengalami peningkatan nilai TDS dan nilai rejeksi yang didapatkan semakin menurun.

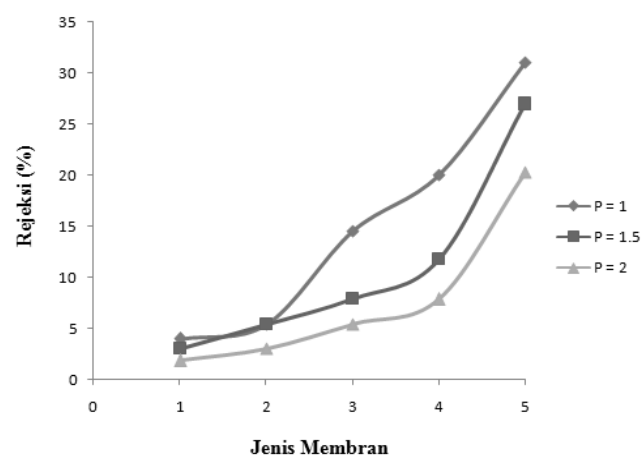

Gambar 6. Grafik hubungan antara jenis membran dengan \% rejeksi tds masing-masing tekanan

Rejeksi terhadap TDS oleh membrane terutama memang ditentukan oleh porositas membrane. Jadi makin kecil ukuran pori karena silica yang makin banyak, maka rejeksi akan makin tinggi. Berkurangnya rejeksi karena tekanan yang makin meningkat berkaitan dengan sifat elastisitas membran.

\section{KESIMPULAN}

Dari penelitian yang telah dilakukan terhadap pengolahan limbah cair kelapa sawit menggunakan membran berbasis kitosan, PVA dan silika dapat disimpulkan bahwa dalam kondisi optimum penurunan parameter didapatkan pada membran 5 dengan komposisi Kitosan:PVA:Silika (70\%:25\%:5\%). Kondisi optimum rejeksi parameter COD sebesar $92,5926 \%$, BOD dengan $56,75 \%$, TDS sebesar $31,0985 \%$, dan $\mathrm{pH}$ sebesar $5,38765 \%$ berada pada tekanan 1 ba, maka dalam penelitian ini membran Kitosan, PVA, dan silika memiliki potensi untuk menurunkan kandungan parameter seperti COD, BOD, TDS, dan juga $\mathrm{pH}$ pada limbah cair kelapa sawit. 


\section{DAFTAR PUSTAKA}

1. Rahayu A, Sri. Konversi Pome Menjadi Biogas. Buku Panduan Online: Pengembangan Proyek di Indonesia. 2015.

2. Ariadi H, D.Reni, Yulastri. Aplikasi Plasma Dengan Metoda Dielectric Barrier Discharge (DBD) untuk Pengolahan Limbah Cair Kelapa Sawit. Jurnal IImiah Online, Vol : 2 No

2 . http://jnte.ft.unand.ac.id/index.php/j nte/article/download/85/80. 2013. Accessed March 19, 2017.

3. Renata, Erisna A, Putri. Pengolahan Limbah Cair Kain Jumputan dengan Menggunakan Membran Kitosan-PVA. Laporan Akhir Polsri. 2014.

4. Farha, Indah F, Kusumawati N. Pembuatan Membran Komposit Kitosan-PVA dan Pemanfaatannya pada Pemisahan Limbah Pewarna Rhodamin-B. Prosiding Seminar Nasional Kimia Unesa. Surabaya : Unesa. 2012.

5. Tetuko A. Sintetis Membran Komposit Kitosan-silika sebagai Adsorben Zat Warna Tekstil. Jurnal IImiah Online. 2016. Accessed February 28, 2017.

6. Wahyuni S. Penggunaan Membran Kitosan untuk Penurunan $C O D$ dan BOD Limbah Cair Kelapa Sawit. Jurnal IImiah Online Menara Perkebunan, 84 (1) , 22 - 28. 2016. Accessed February 28, 2017.

7. Cheng. Adsorption Kinetic Character of Copper Ionsonto a Modified Chitosan Transparent Thin Membrane from Aqueous Solution. 2010.

8. Wenten I.G. Teknologi Membran Industrial. Bandung : Teknik Kimia ITB. 1999.

9. S, Kimura. Transport Phenomena in Membrane Separation. Seminar Tamu Teknik Kimia ITB hal 1-27. Bandung : ITB. 1992.

10.Mulder, Marcel. Basic Principles of Membran Technology $2^{\text {nd }}$ edd. London : Kluwer Academic Publisher. 1996.

11.Nasir S, Budi T, Silviaty I. Aplikasi Filter Keramik Berbasis Tanah Liat Alam dan Zeolit pada Pengolahan Air Limbah Hasil Proses Laundry.
Jurnal Bumi Lestari. 13 (1), 45 - 51. 2013.

12.J.Hazard Mater.182, 408 - 415.Cotton FA, Geoffrey Wilkinson. 1998. Advance Inorganic Chemistry $5^{\text {th }}$ edition. John Wiley and Sons. New York.

13.Bragmann, C.P and Goncalves, M.R.F. 2006. Thermal Insulators Made With Rice Husk Ashes: Production and Correlation Between Properties and Microstructure. Department of Materials, School of Engineering, Federal university of Rio Grande do Sul, Brasil. 
Pengolahan Limbah Cair Kelapa Sawit Menggunakan Membran Berbasis Kitosan, Pva, Dan Silika...Ida Febriana, Siti

Chodijah, Husaini, Liza Novriani 